\title{
PELAKSANAAN IBADAH HAJI ABAD KE 19 DAN DAMPAKNYA TERHADAP PERLAWANAN RAKYAT KEPADA KOLONIALISME BELANDA
}

\author{
Istikomah \\ IAIN Syekh Nurjati Cirebon (istikomahisti37@gmail.com)
}

\begin{abstract}
The Hajj, in the 19th century, was a tool for transmitting religious culture and doctrine. The challenge that faced by prospective pilgrims is derived from the Dutch government as a pilgrims manager or administrator. Rules which applied before the departure until their arrival from Mecca (Holy Land) greatly complicate the congregation. The rise of social status after the pilgrimage had its own influence on society, the hajj had significant meaning and influence in the 19th century. It was able to mobilize the social and cultural forces against the Dutch. Therefore, the Dutch Indies government enacted a special policy related to pilgrimage whose purpose is to minimize the number of pilgrims from Indonesia. But in the end, the hajj policy doesn't give a significant impact to the pilgrims. Therefore, still appears the resistance of Muslims led by Islamic leaders who has appellation "hajj".
\end{abstract}

Keywords: hajj, colonialism, resistance

\begin{abstract}
Abstrak
Haji pada abad ke 19 merupakan alat untuk mentransmisikan budaya dan doktrin agama. Tantangan yang dihadapi oleh calon jamaah haji yakni berasal dari pemerintah Belanda sebagai pengelolah haji. Peraturan yang diterapkan mulai dari sebelum berangkat sampai sepulang dari Tanah Suci sangat mempersulit jamaah. Naiknya status sosial setelah menunaikan haji memiliki pengaruh tersendiri bagi masyarakat, haji memiliki makna dan pengaruh yang signifikan pada abad ke 19 . Yakni mampu menggerakkan kekuatan sosial dan kultural untuk melawan Belanda. Oleh karena itu, Belanda memberlakukan kebijakan khusus terkait ibadah haji yang tujuannya untuk meminimalisir jumlah jamaah haji dari Indonesia. Namun pada akhirnya kebijakan haji tersebut tidak memberikan dampak yang berarti bagi jamaah haji. Sehingga tetap muncul perlawanan-perlawanan umat Islam yang dipimpin oleh para pemuka agama Islam yang bertitel haji.
\end{abstract}

Kata Kunci: Haji, Kolonialisme, Perlawanan

\section{A. Pendahuluan}

Haji merupakan sebuah ajang untuk mentransmisikan suatu budaya dan doktrin-doktrin. Pada tahap awal islamisasi, jalur perdagangan adalah di antara jalur utama bagi transmisi budaya dan agama ini. Namun di abad-abad selanjutnya, haji menjadi saluran penting bagi penyebaran budaya dan agama, di samping jaringan-jaringan perdagangan yang terus berlanjut meskipun terus berkurang, hubungan diplomatik, imigrasi arab, dan lebih penting lagi kemunculan mesin cetak yang berimplikasi pada peningkatan produksi dan distribusi teks-teks dan surat kabar (Didin Nurul Rosidin, 2012). Di Indonesia, ketika seseorang telah menunaikan ibadah 
haji, secara otomatis gelar Haji akan menempel pada namanya. Gelar haji tersebut sejak berabad-abad lamanya sudah dipergunakan, walaupun pemerintah Belanda sempat melarang pemakaian gelar haji tersebut tapi sampai sekarang para haji dengan mudah menggunakan gelar tersebut. Kemungkinan besar gelar itu bermula dari status sosial seseorang haji, yang secara ekonomi telah mampu berangkat ke Mekkah, dan juga memiliki ilmu pengetahuan agama yang memadai, sehingga kebanyakan mereka lebih dituakan, menjadi imam salat, pembaca doa waktu kenduri dan sebagainya (Yusliani Noor, 2014).

Pelaksanaan ibdah haji di Indonesia pada zaman sekarang dan dulu sangat berbeda. Untuk jamaah haji sekarang sangat mudah sekali namun hanya bersabar untuk menunggu antrian beberapa tahun. Dahulu khususnya pada masa penjajahan Belanda, jamaah haji sangat dipersulit oleh pemerintah, hal ini karena pemerintah yang mengurusi ibadah haji adalah orang non Islam. Hal tersebut bukan alasan utama yang mendasari dipersulitnya jamaah haji melainkan karena pengaruh dari para haji yang melakukan perlawanan terhadap Belanda yang dibungkus dengan gerakan-gerakan sosial. Sehingga pemerintah Belanda menetapkan kebijakan-kebijakan dengan tujuan memperketat pelaksanaan haji agar tidak ada perlawanan yang didapatkan dari para haji. Puncak problematika haji pada masa penjajah Belanda terjadi pada abad ke-19, di mana terjadi pelonjakan jamaah haji sehingga memaksa pemerintah Belanda untuk mengeluarkan kebijakan, namun kebijakan tersebut justru malah membuat jamaah haji semakin terus meningkat (Sartono Kartodirjo, 1984).

Implikasi politik ibadah haji jelas sekali. Ia sesungguhnya muktamar abadi dari Pan Islamisme, di mana segala urusan agama dibicarakan oleh delegasi-delegasi dari tiap penjuru dunia Islam, di mana urusan-urusan agama dibicarakan dalam pertemuan tersebut, seperti pertahanan dan penyebaran Islam. Tokoh-tokoh kebangkitan Islam yang militan merasa terpanggil hatinya, dan ketika mereka kembali ke tanah asalnya mereka melakukan pembaharuanpembaharuan atas dasar doktrin yang mereka dapatkan ketika berhaji. Ulama Timur Tengah yang sudah melakukan pembaharuan antara lain Jamaluddin al Afghani yang melakukan pembaharuan di Mesir yakni yang dikenal dengan gerakan Pan Islamisme. Muhammad bin Abdul Wahab yang melakukan 
pembaharuan melalui gerakan Wahabi di Saudi Arabia, yang kemudian gerakan ini disebarkan oleh jamaah haji yang berasal dari berbagai daerah, salah satunya adalah Indonesia. Terbukti ketika jamaah haji Indonesia datang ke Tanah Suci, mereka mendapatkan Paham Wahabi, dan ketika pulang ke Indonesia mereka menyebarkan paham tersebut sebagaimana yang telah dilaksanakan oleh Haji Miskin, Haji Sumanik dan Haji Piabang di Minangkabau (Sumatera Barat) (Stoddard Lothrop, 1966).

Menurut Raffles dalam bukunya yang berjudul History of Java yang dikutip oleh Karel A Steenbrink menyebutkan bahwa di dalamnya terkandung dua aspek negatif para haji yang ditulis dalam buku ini. Pertama, mereka dianggap sebagai orang istimewa dan suci, sehingga rakyat sederhana terlalu cepat berkesimpulan bahwa mereka mempunyai kekuatan gaib. Kedua, ada unsur politik, karena dengan adanya pemikiran seperti ini, para haji mempunyai pengaruh politik dan sering berperan sebagai pemimpin pemberontakan terhadap orang Eropa (Karel A Steenbrink, 1984).

Ulama Mekkah mempunyai peran dalam perlawanan yang dilakukan umat Islam di Indonesia. Ketika Koloni Jawa belajar di
Mekkah, ulama Mekkah menyadarkan orang Islam Indonesia untuk melakukan perlawanan terhadap Kolonial Belanda. (Azyumardi Azra, 2013). Snouck meneliti Koloni Jawa yang bermukim di sana, karena orang yang hanya datang untuk berhaji dan kembali lagi ke Indonesia tidak memberikan dampak politik. Orang yang bermukim akan terpengaruh oleh ortodoksi Islam, terlebih ketika gerakan Pan Islamisme sudah marak sampai pada Mekkah. Pan Islamisme ini bertujuan mempersatukan umat Islam, melawan penjajah-penjajah kafir yang memasuki wilayah Islam. Doktrin-doktrin tersebut mereka dapatkan di sana dan terus disebarluaskan kepada Koloni-koloni Jawa lainnya, baik dengan berdiskusi ataupun korespondensi. Kolonikoloni Jawa yang seperti ini yang nantinya ketika pulang ke Indonesia akan menjadi pembaharu-pembaharu di daerahnya masing-masing. Seperti H. Wasid dengan Pemberontakan Petani Banten pada 1888, H. Sumanik, H. Piabang dan H. Miskin dengan Perang Padri. Kemudian pada perkembangannya pada abad ke-20 perlawanan yang dilakukan bukan berbentuk perang, namun dalam bentuk pemikiran. Seperti KH. Hasyim Asy'ari dengan NUnya, KH.Ahmad Dahlan dengan gerakan Muhammadiyahnya. 
Ibadah haji mempengaruhi munculnya gerakan-gerakan Islam yang memberikan dampak politik bagi pemerintah Belanda, yakni gerakan perlawanan. Gerakan tersebut antara lain adalah dalam bentuk Tarekat dan Pesantren. Dari gerakan-gerakan tersebut akan melahirkan perlawanan yakni perang. Tarekat dan pesantren tersebut digerakkan oleh para haji yang telah pulang dari Tanah Suci (Mekkah), tarekat dan pesantren merupakan gerakan persaudaraan Islam (Sartono Kartodirjo, 1984). Haji yang memerankan penyebaran gerakan persaudaraan Islam tersebut, karena ketika haji, seluruh umat Islam bisa bertemu dan bertukar fikiran mengenai keadaan tanah airnya (Stoddard Lothrop, 1966). Bangkitnya Islam yang ditandai dengan melonjaknya jamaah haji dilatarbelakangi oleh peran bupati pada saat itu. Bupati sebagai pemerintah harus selalu memerintahkan rakyatnya untuk menjalankan ibadah mereka. Akibatnya terjadi kebangkitan Islam yang berdampak pada kekuasaan pemerintah kolonial Belanda. Diawali dengan melonjaknya jamaah haji yang kemudian menghasilkan berkembangnya pesantren-pesantren serta gerakan-gerakan tarekat yang semua itu merupakan perlawanan politik yang dibungkus dengan gerakan sosial umat Islam. Munculnya gerakan sosial umat Islam sebagai bentuk perlawanan terhadap penjajah berasal dari ibadah haji di mana pada haji di dalamnya ada gerakan persaudaraan umat Islam. Hal yang menjadi tolok ukur kebangkitan Islam adalah ibadah haji. Dari haji pula para pemerintah Belanda merasa terancam kekuasaannya sehingga mengeluarkan kebijakan-kebijakan yang bertujuan meminimalisir umat Islam yang berangkat haji. Munculnya perlawanan dari dua gerakan sosial tersebut adalah meletusnya beberapa peperangan (Sartono Kartodirjo, 1984).

\section{B. Makna dan Kedudukan Haji Pada di Masyarakat}

Haji merupakan suatu ritual yang mampu menumbuhkan sikap manusia berfikir tentang politik dan sosial sehingga haji kemudian menjadi konvensi sosial politik terbesar dan sangat spektakuler yang pernah terjadi di dunia. Berjuta orang datang dari berbagai penjuru dunia, yang mencerminkan beragam etnis, bahasa, budaya, adat dan beragam aliran berinteraksi satu sama lain dalam koridor ajaran Islam (Dien Majid, 2008). Haji menjadi konferensi terbesar dunia karena setiap muslim dari berbagai negara saling bertukar fikiran dengan yang 
lainnya sehingga tidak menutup kemungkinan politik berperan di dalam haji. Namun pada perkembangannya pengertian haji bergeser yakni haji merupakan sebuah ajang untuk mentransmisikan suatu budaya dan doktrin-doktrin. Pada tahap awal islamisasi, jalur perdagangan adalah di antara jalur utama bagi transmisi budaya dan agama ini. Namun di abad-abad selanjutnya, haji menjadi saluran penting bagi penyebaran budaya dan agama. Haji bukan hanya saling membicarakkan permasalahan yang ada di masing-masing Negara, namun haji mampu menularkan kebudayaan, ilmu, doktrin-doktrin dan cara berfikir orang Timur Tengah ke Indonesia. Dapat dibuktikan dengan banyaknya paham atau gerakan-gerakan Islam yang berasal dari Timur Tengah yang masuk ke Indonesia melalui haji (Didin Nurul Rosidin, 2012).

Haji sebagai rukun Islam yang kelima memiliki nilai historis yang berbeda. Sejarah haji tidak berhenti pada Nabi yang mensyariatkannya saja. Namun setiap abad memiliki sejarah pelaksanaan ibadah haji yang berbeda. Seperti halnya di Indonesia pada abad ke 19 memiliki sejarah problematika yang sangat kompleks. Pada periode awal perjalanan haji dari Indonesia sangat tergantung pada keadaan transportasi antara kepulauan Nusantara dengan Jazirah Arab. Hubungan antara dua wilayah dilaksanakan melalui pelayaran perdagangan dan berkaitan erat dengan masuk dan tersebarnya Islam serta pembentukan komunitas muslim di Indonesia. Pelayaran, Perdagangan, Islamisasi serta pembentukan komuitas merupakan faktor-faktor pendorong haji di Indonesia. Pelaksanaan haji di Indonesia tergantung pada alat transportasinya, semakin canggih alat transportasi yang digunakan dan semakin mudahnya akses maka semakin melonjak pula jumlah jamaah haji (Shaleh Putuhena, 2007). Pada perkembangannya haji menjadi ajang untuk mentransmisikan budaya dan agama, di samping perdagangan masih berperan. Haji sebagai media untuk menularkan budaya serta keilmuan yang berasal dari Timur Tengah. Hal terpenting adalah menularkan keilmuan, keilmuan menjadi alat untuk menularkan apa yang didapatkan dari Timur Tengah, keilmuan yang didapatkan kemudian dikembangkan sampai pada akhirnya melahirkan gerakan perlawanan terhadap Kolonial. Para haji yang menimba ilmu di sana, tentunya sekaligus mendapatkan doktrindoktrin yakni benih-benih nasionalisme sehingga menjadikan 
para haji sebagai penggerak perlawanan terhadap Kolonial.

Jamaah haji yang datang ke Tanah Suci memiliki tujuan tertentu selain menunaikan Rukun Islam yang kelima. Ada beberapa golongan yang bertujuan pergi ke Tanah Suci untuk berdagang, mengabdikan hidupnya di Tanah Suci dan ingin menimba ilmu kepada ulama Timur Tengah. Namun terdapat pula orangorang yang hanya pergi ke Tanah Suci hanya untuk menunaikan ibadah haji, kelompok ini yang tidak memberikan dampak politik terhadap Kolonial Belanda (Azyumardi Azra, 2013). Berbeda dengan kalangan raja atau sultan, para sultan acap kali mendapat gelar (sultan) dari Mekah, dengan demikian seakan-akan memperoleh pengesahan sakral bagi kedudukan tinggi mereka, sebagai contoh Sultan Muhammad Maulana Matarani (Sultan Agung) tahun 1613-1645 dan Sultan Ageng (16501682). Dalam hal ini bukan hanya Sultan saja yang berangkat, ketika Sultan tidak dapat berangkat sendiri ke Tanah Suci maka menyuruh wakilnya untuk pergi agar mendapat pengakuan kekuasaan dari Mekah (Dick Douwes dan Nico Kaptein, 1997).

\section{Faktor Meningkatnya Pelaksanaan Ibadah Haji Abad Ke 19}

Jalur perdagangan yang dilalui pada masa itu melalui Pelabuhan Hormuz, Aden serta pelabuhan yang ada di Mesir. Ketika Dinasti Mamluk berkuasa nasib Pelabuhan Jeddah berubah, dengan memperbaiki hubungan dagang dengan Eropa dan dihapuskannya pembatasan memasuki Laut Merah. Dengan demikian, Pelabuhan Jeddah dijadikan sebagai pelabuhan utama Laut Merah dan pada akhirnya Pelabuhan Jeddah menjadi Pelabuhan Internasional. Dengan dijadikannya Pelabuhan Jeddah sebagai pelabuhan internasional bukan hanya para pedagang saja yang tertarik namun para pecinta ilmu pun mulai berbondong-bondong pergi ke Tanah Suci untuk menimba ilmu (Azyumardi Azra, 2013).

Faktor lain yang mendorong kesadaran untuk melaksanakan haji selain aksesnya yang mudah adalah terjadinya kebangkitan keagamaan pada masyarakat Indonesia. Selama beberapa dasawarsa, sebagian besar Pulau Jawa dilanda gerakan kebangkitan kembali kehidupan agama, yang memperlihatkan peningkatan yang sangat luar biasa dalam kegiatan agama, seperti melakukan salat, naik haji, memberikan pendidikan Islam tradisional kepada anak-anak muda, mendirikan cabang-cabang tarekat, penyelenggaraan khotbah yang 
meluas, dan sebagainya (Sartono Kartodirjo, 1984). Kondisi sosial masyarakat yang sudah menyadari pentingnya kehidupan agama diawali dengan keresahan sosial yang terusmenerus sehingga mendorong peningkatan kegiatan keagamaan. Kondisi tersebut menjadikan meningkatnya jumlah orang yang ingin naik haji. Sebelumnya hanya ada beberapa orang naik haji yang hanya menyadari haji sebagai kewajiban seorang muslim. Setelah aksesnya yang semakin mudah dengan alat transportasi yang semakin canggih serta dibukanya pelabuhan internasional di samping sudah terbangunnya kesadaran masyarakat untuk beribadah menjadikan banyaknya orang yang ingin melaksanakan ibadah haji.

Pada pertengahan abad ke-19 jumlah jamaah haji mengalami peningkatan terus menerus. Pada sekitar tahun 1850-1860 jumlah jamaah haji sudah mencapai rata-rata 1.600 orang. Terlebih sejak dibukanya Terusan Suez pada tahun 1869 di mana kondisi transportasi laut sudah lebih baik, jumlah jamaah haji sudah kian meningkat saja. Dalam tahun 1870-an, jumlahnya hampir mencapai 2.600 orang. Sedang menurut Dick Douwes dan Nicao Kaptein dalam karangannya yang berjudul "Indonesia dan Haji" menyebutkan bahwa pada tahun
1870 jumlah jamaah haji meningkat menjadi 3258 orang. Dan dalam 1880-an meningkat hampir dua kali lipat menjadi 4.600 orang (Darul Aqsha, 2005). Dilihat dari statistik jumlah jamaah haji yang berangkat dan jumlah jamaah haji yang pulang berbeda, karena banyak dari jamaah haji yang memilih untuk menimba ilmu terlebih dahulu di sana, ada yang terserang penyakit lalu meninggal dunia, selain itu memilih untuk menetap di Tanah Suci untuk mencari penghidupan. Orang-orang yang menetap di sana disebut "Koloni Jawa". Koloni-koloni Jawa tersebut yang akan membahayakan Pemerintah Imperial Belanda, karena orang yang hanya murni melakukan ibadah haji tidak memberikan dampak politik terhadap Belanda. Koloni Jawa tersebut yang nantinya akan memberikan dampak politik dengan melakukan perlawanan terhadap pemerintah Belanda.

\section{Kebijakan Kolonialisme Belanda Terhadap Ibadah Haji}

1. Kebijakan Tahun 1810

Pemerintah Belanda pertama yang mengatur urusan perhajian adalah Deandels. Pada tahun 1810 Pemerintah Belanda Jenderal Deandels mengeluarkan kebijakan bahwa setiap orang yang ingin pergi dari Jawa ke tempat yang lain maka harus menggunakan pas jalan dengan 
alasan ketertiban dan keamanan (Shaleh Putuhena, 2007). Hal itu karena menurutnya dianggap banyak gangguan mengancam. Untuk itu, diberlakukan adanya pas jalan (Dick Douwes dan Nico Kaptein, 1997). Peraturan yang dikeluarkan Deandels ini berdasarkan Stbl. No. 42, 1859. Pejabat yang mengatur pas jalan di daerah Jawa dan Madura diatur oleh wedana dan asisten wedana. Dengan begitu urusan pas jalan diatur oleh pejabat pribumi. Sedangkan untuk daerah luar Jawa dan Madura diatur oleh pejabat Belanda, yaitu controleur dan yang mengatur visa untuk jamaah haji yang berangkat dari Indonesia adalah kepala pelabuhan (Shaleh Putuhena, 2007).

Peraturan tersebut diberlakukan selain untuk keamanan juga sebagai alat Belanda untuk mengetahui jumlah jamaah haji yang berangkat. Tujuan dari kebijakan tersebut untuk mempersulit jamaah haji yang hendak berangkat sehingga diharapkan jamaah haji lebih sedikit untuk berangkat. Pada kenyataannya jamaah haji mematuhi kebijakan Belanda tersebut sehingga tidak mampu meminimalisir jumlah jamaah haji.

\section{Kebijakan Tahun 1811}

Pada tahun 1811-1814 Indonesia dikuasai Inggris di bawah Jenderal Raffles. Pemerintah Inggris di bawah kekuasaan Raffles sangat tertarik kepada kebudayaan Jawa, namun menganggap bahwa Islam merupakan unsur yang berbahaya. Raffles sangat jelas menggambarkan peranan para haji yakni orang Arab dari Mekkah dan orang Jawa yang kembali dari Mekkah akan berlagak seperti orang suci. Masyarakat pun akan menaruh hormat serta mematuhi perintah mereka. Karena dianggap memiliki kekuatan gaib, sehingga para haji tampil sebagai pemimpin pemberontakan (Dick Douwes dan Nico Kaptein, 1997). Pada 1811 pemerintah Inggris mengeluarkan surat edaran kepada para gubernur untuk berhati-hati kepada Sayid dan "pastor pribumi". Karena mereka dianggap akan mengancam kekuasaan kolonial (Karel A Steenbrink, 1984). Sehingga seorang pegawai Raffles yang bernama Macquoid, melaporkan adanya bupati yang meninggal namun kedua anaknya tidak diperbolehkan menjadi penggantinya dengan alasan yang satu seorang haji (datang dari Mekkah) dan yang satu sedang melaksanakan haji (di Mekkah) (Dick Douwes dan Nico Kaptein, 1997). Kebijakan tersebut membuat para haji yang pulang dari Tanah Suci diawasi oleh pemerintah. Dengan begitu para haji tidak mendapatkan jabatan sebagai pegawai pemerintah. 
3. Kebijakan Tahun 1825-1831

Pada 1825 calon jamaah haji harus membayar f 110 (110 gulden) untuk mendapatkan paspor haji. Dengan adanya kebijakan tersebut jamaah haji tidak mau membayar paspor sehingga banyak haji ilegal dikarenakan tidak terdata melalui paspor. Belanda terus meningkatkan usahanya untuk membendung jumlah jamaah haji. Pada 1831 diberlakukan denda bagi setiap jamaah haji yang tidak mempunyai paspor sebesar $\mathrm{f}$ 1000, dan selanjutnya berubah menjadi f 220. Peraturan 1831 yakni dikuranginya denda karena 1000 gulden sangat tinggi. Peraturan tersebut ditetapkan secara umum, tetapi tidak diumumkan secara resmi dalam saatsblad. Peraturan tersebut pun hanya diberlakukan di Jawa dan Madura, karena daerah lain belum berada di bawah kekuasaan Belanda (Karel A Steenbrink, 1984), Karena peraturan tersebut tidak mampu membendung jumlah calon jamaah haji yang terus meningkat. Peraturan yang dibuat yakni dengan membayar denda tidak bisa berjalan efektif, karena banyak jamaah yang tidak mau membayar denda dengan berangkat melalui Sumatera.

\section{Kebijakan Tahun 1852}

Pada tahun 1852 terjadi regulasi kebijakan yakni kedua kebijakan tersebut dicabut namun kebijakan untuk mempunyai paspor masih tetap diberlakukan namun diberikan secara gratis dan denda dihapuskan. Duynmaer van Twist mencabut kedua resolusi pada tahun 1852 dan menggantikannya dengan resolusi yang ketiga: paspor haji masih diwajibkan tetapi pajak untuk itu dihapuskan (Dick Douwes dan Nico Kaptein, 1997). Keputusan tersebut berdasarkan Bt 3 Mei 1852 no. 9, pas jalan tetap diberlakukan namun diberikan secara gratis, sedangkan untuk denda dihapuskan. Alasan pemerintah Belanda menghapuskan peraturan tersebut karena tidak berhasil membendung jumlah calon jamaah haji yang terus bertambah. Kemudian pemerintah Belanda terus membicarakan kebijakan-kebijakan yang mampu membendung jumlah jamaah haji agar tidak ada orang yang pergi ke Tanah Suci (Karel A Steenbrink, 1984). Kebijakan tahun 1825-1831 terkesan mencampuri urusan keagamaan pribumi sehingga dilakukannya regulasi kebijakan.

\section{Kebijakan Tahun 1859}

Pada 1859 terjadi regulasi kebijakan di mana kebijakan ini berbeda dengan kebijakan sebelumnya, namun kebijakan tersebut yang digunakan sampai tahun 1902. Pada tahun ini pemimpin pemerintah Belanda adalah Pahud seorang yang konservatif. Ia akan mengambil tindakan kepada golongan yang 
membahayakan

Peraturan yang dikeluarkan dilatarbelakangi oleh terjadinya Perang Mutiny atau pemberontakan Sepoy di Hindia Inggris yang banyak menewaskan orang Eropa. Belanda khawatir jika orang Indonesia akan melakukan pemberontakan yang demikian. Sehingga mengeluarkan peraturan sebagai berikut:

a) Calon haji harus meminta pas jalan pada bupati, tanpa ongkos resmi;

b) Calon haji harus membuktikan kapada bupati bahwa dia mempunyai uang yang cukup banyak untuk pembayaran biaya perjalanan pulang pergi ke Mekkah, dan biaya hidup keluarganya di Indonesia;

c) Sesudah pulang dari Mekkah para jemaah harus diuji oleh bupati atau orang yang ditunjuk oleh bupati dan setelah itu baru diperkenankan memakai gelar dan pakaian haji.

6. Kebijakan Tahun 1872

Berkenaan dengan makin bertambahnya jumlah jemaah haji, maka pemerintah Belanda membuka kantor konsulat di Jedah pada tahun 1872 (Dick Douwes dan Nico Kaptein, 1997). Kantor konsulat Belanda yang fungsinya untuk mengawasi jamaah haji dari
Indonesia, konsulat bertugas memeriksa pas jalan para jamaah haji, dan konsulat bertanggung jawab terhadap keberadaan jamaah haji Indonesia di Tanah Suci. Pegawai atau konsul ini sebagai pegawai Departemen Luar Negeri, kantor ini yang nantinya akan berkembang sampai sekarang menjadi Kedutaan Besar di Arab. Dengan adanya pengawasan di Jeddah, Belanda akan lebih mudah mendapatkan informasi tentang aktivitas jamaah haji di Tanah Suci, jumlah jamaah lebih mudah diketahui, dan masalahmasalah yang dihadapi jamaah haji di Tanah Suci akan terungkap. Konsul Belanda akan bertanggungjawab terhadap masalah yang dihadapi mereka, tentu dengan adanya kantor konsulat di Jeddah dapat memberikan kemudahan jamaah haji dalam menjalankan ibadah hajinya walaupun sebenarnya Belanda memiliki motif lain dalam mendirikan kantor konsulat di Jeddah. Usaha konsul Belanda yang jelas bagi pengawasan terhadap jamaah haji adalah dengan diberikannya kartu untuk jamaah, Mekapassen adalah sebutan kartu Mekkah yang diberikan oleh konsul Belanda kepada jamaah haji. Kartu ini berfungsi sebagai tanda pengenal jamaah haji dari Hindia Belanda dan yang terpenting adalah untuk meminta tolong kepada konsul 
apabila mereka mendapatkan kesulitan di Tanah Suci (Francien Van Anrooij, 2014).

7. Kebijakan Tahun 1899

Pada 1889 Snouck datang ke Indonesia setelah dua tahun sebelumnya telah mengirim surat kepada Pemerintah Hindia Belanda meminta untuk datang ke Indonesia. Kerjasamanya sudah terjalin lebih dahulu dengan Van Heutz namun ia juga dijadikan penasehat urusan pribumi dan Arab yang sekarang menjadi Departemen Agama (Aqib Suminto, 1985). Nasehat yang diberikan oleh Snouck lebih lembut daripada kebijakan yang sudah diterapkan. Seperti yang sudah diterapkan sebelumnya, kebijakan yang sudah berlaku semuanya diganti dengan kebijakan-kebijakan politik haji. Mengingat kebijakan sebelumnya tidak efektif karena justru kebijakan tersebut membuat para haji tidak gentar untuk melakukan haji. Snouck memberikan nasehat serta menceritakan keadaan orang yang haji di Tanah Suci (Dick Douwes dan Nico Kaptein, 1997).

Nasehat yang diberikan oleh Snouck lebih lembut daripada kebijakan yang sudah diterapkan. Seperti yang sudah diterapkan sebelumnya, kebijakan yang sebelumnya semuanya diganti dengan kebijakan-kebijakan politik haji. Mengingat kebijakan sebelumnya tidak efektif karena justru kebijakan sebelumnya membuat para haji tidak gentar untuk melakukan haji. Snouck memberikan nasehat serta menceritakan keadaan orang yang haji di Tanah Suci. Snouck ketika dijadikan sebagai penasehat pribumi, ia memberikan nasehat untuk menghadapi haji-haji Indonesia berdasarkan pengetahuannya tentang aktivitas jamaah haji di Mekkah, karena ia meneliti langsung gerak-gerik Koloni Jawa di Tanah Suci. Orang Indonesia sangat diterima oleh orang Mekkah karena merasa mempunyai hubungan persaudaraan yaitu Islam. Orang-orang Mekah tampaknya besar toleransi mereka terhadap hubungan internasional yang terus menerus, untuk segala macam pembaharuan diterima dengan baik di Mekah, jika cara memperkenalkannya mengena di hati. Tetapi tidak untuk orang Eropa! jelas di sini mereka dikuasai oleh perasaan permusuhan. Peristiwa politik baru-baru ini di Mesir dan Sudan telah mempertajam "kefanatikan" ini (C. Snouck Hurgronje, 1996). Oleh karenanya ketika Snouck memasuki Kota Mekkah, ia harus berpura-bura masuk Islam dan mengganti namanya dengan Abdul Ghaffar. Dengan begitu ia bisa belajar Islam kepada ulama-ulama Mekkah serta 
mengawasi aktivitas jamaah haji di sana. Atas dasar itulah Snouck memberikan nasehat kepeda Pemerintah Belanda.

\section{E. Dampak Pelaksanaan Ibadah Haji Bagi Perlawanan Umat Islam Terhadap Kolonialisme Belanda}

Ibadah haji merupakan satu sumber sosial bagi revitalisasi kehidupan agama (Sartono Kartodirjo, 1984). Paradigma yang dibangun oleh masyarakat adalah bahwa haji dapat merubah keadaan keagamaan di suatu masyarakat. Pemurnian agama dapat dilakukan oleh seseorang yang telah melaksanakan ibadah haji. Hal itu disebabkan karena haji memiliki prestise tersendiri di mata masyarakat. Orang yang melaksanakan haji, sepulang dari hajinya akan dianggap sebagai orang yang memiliki banyak ilmu agama walaupun sebelumnya tidak memiliki pemahaman agama yang lebih. Mereka akan dianggap sebagai kiyai atau pemimpin tarekat, karena pada kenyataanya seorang haji mendapatkan pemahaman tarekat dari Mekkah serta banyak menimba ilmu agama oleh ulama Timur Tengah. Dengan begitu mereka akan menyebarkan apa yang didapatkan dari sana. Telah disebutkan di bab sebelumnya bahwa tidak semua golongan haji memberikan dampak politik terhadap Belanda, namun hanya orang-orang yang melaksanakan haji kemudian memperpanjang masa hajinya dengan menimba ilmu oleh ulama Timur Tengah. Menurut Bangsa Eropa orang-orang yang menunaikan ibadah haji ditanamkan perasaan permusuhan terhadap penguasapenguasa Kristen di Tanah Air mereka, sehingga kerusuhankerusuhan yang terjadi di Indonesia pada abad ke 19 telah menyebabkan perhatian penguasa kolonial semakin ditujukan kepada pengaruh yang datang dari Mekkah.

Implikasi dari pelaksanaan ibadah haji adalah gerakan-gerakan sosial sebagai bentuk perlawanan terhadap penjajah, yakni gerakan pembaharuan Islam, gerakan tarekat dan berkembangnya pesantrenpesantren. Gerakan tarekat bukan hanya gerakan keagamaan saja, melainkan juga tarekat dibawa dan disebarkan oleh para haji yang datang dari Tanah Suci karena mereka menganut sebuah tarekat yang mereka dapatkan dari Mekkah. Gerakan tarekat ini bukan hanya melakukan praktik-praktik keagamaan namun yang lebih penting mereka menumbuhkan sikap yang tidak toleran dan fanatik terhadap muridnya. Sesungguhnya mereka menjadi bukan hanya pusatpusat kebangkitan agama melainkan 
juga pusat-pusat protes politik. Protes politik tersebut yang akan melancarkan perlawanan terhadap pemerintah kolonialisme Belanda (Sartono Kartodirjo, 1984).

\section{F. Penutup}

Dari pemaparan di atas, dapat ditarik beberapa poin untuk menjawab rumusan masalah dalam tulisan ini, di antaranya sebagai berikut:

a) Pelaksanaan ibadah haji abad ke 19 memiliki tantangan tersendiri bagi para jamaah. Calon jamaah haji dipersulit keberangkatannya dikarenakan pengelola urusan haji adalah penjajah Belanda. Berbagai kebijakan yang harus dipatuhi oleh calon jamaah haji, seperti adanya pas jalan, calon jamaah harus dikarantina terlebih dahulu, harus mematuhi pemerintah Belanda di Jeddah serta sepulang dari Tanah Suci jamaah harus diuji oleh pemerintah dengan tujuan menghindari jamaah yang hendak memberontak kepada Belanda. Namun pada kenyataannya jamaah haji justru merasa tertantang untuk melaksanakan ibadah haji. Kebijakan yang dikeluarkan Belanda tidak dapat membendung jumlah calon jamaah haji pada abad ke 19 .
Jamaah haji pada abad ke 19 memiliki pengaruh politik bagi Belanda. Oleh karena itu Belanda terus berusaha meminimalisir jumlah jamaah haji dengan tujuan dapat melestarikan penjajahan di Indonesia.

b) Ibadah haji abad ke 19 memiliki makna dan pengaruh yang signifikan. Haji yang dianggap sebagai ajang transmisi keilmuan, budaya, dan doktrin ini memberikan dampak bagi perlawanan umat Islam terhadap Belanda. Makna haji yang memiliki nilai istimewa pada masyarakat membuat keberadaan para haji diperhitungkan. Seseorang yang pulang dari haji dianggap memiliki kemampuan agama yang lebih dan memiliki kekuatan supranatural, sehingga para haji sangat dipatuhi oleh masyarakat. Para haji juga mampu menggerakkan kekuatan masyarakat untuk melawan penjajah Belanda yang kafir. Orang kafir dianggap darahnya halal untuk dibunuh menjadikan para haji menghimpun kekuatan untuk melawan penjajah. Sepanjang abad ke 19 perlawanan-perlawanan umat Islam yang terjadi di Indonesia dimotori oleh para haji. 


\section{Daftar Pustaka}

Qurotu, Aini. 2015. Peran Cristian Snouck Hurgronje Terhadap Kebijakan Politik Islam Hindia Belanda (1889-1906). IAIN Syekh Nurjati Cirebon.

Aqsha, Darul. 2005. Kiai Haji Mas Masur (1886-1946) Perjuangan dan Pemikiran. Jakarta: Erlangga.

Arsi Tuti Dini, Skripsi Kebijakan Pemerintah Komunis China dan Respon Muslim Uyghur di Turkestan Timur Tahun 19492015), IAIN Syekh Nurjati Cirebon, 2016.

Azra Azyumardi, Jaringan Ulama Timur Tengah dan Kepuluan Nusantara Abad XVII \& XVIII, Jakarta: Kencana, 2013.

Azra Azyumardi, Renaisans Islam Asia Tenggara Sejarah Wacana \& Kekuasaan, Bandung: PT. Remaja Rosdakarya, 2000.

Douwes Dick dan Kaptein Nico, Indonesia dan Haji, Jakarta: INIS, 1997.

Anrooij Francien Van, diterjemahkan oleh Nurwahyu W. Santoso dan Susi Moeimam, De Koloniale State (Negara Kolonial) 18571942, (Leiden: Arsip Kementerian urusan Tanah Jajahan, 2014.

Hurgronje C Snouck, Kumpulan Karangan Snouck Hurgronje V, Jakarta: INIS, 1996.
Hurgronje C Snouck, Kumpulan Karangan Snouck Hurgronje VI, Jakarta: INIS, 1996.

Kartodirdjo Sartono, Pemberontakan Petani Banten 1888, Jakarta: PT. Dunia Pustaka Jaya, 1984.

Kartodirjo Sartono, Pengantar Sejarah Indonesia Baru: 1500-1900 dari Emporium Sampai Imperium Jilid I, Yogyakarta: Ombak, 2014.

Lapidus Ira M, Sejarah Sosial Umat Islam bagian Ketiga, Jakarta: PT. Raja Grafindo Persada, 2000.

Majid Dien, Berhaji di Masa Kolonial, Jakarta: CV. Sejahtera, 2008.

Noor Yusliani, Sejarah Timur Tengah (Asia Barat daya), Yogyakarta: Ombak, 2014.

Poesponegoro Marwati Djoened dan Notosusanto Nugroho, Sejarah Nasional Indonesia $V$, Jakarta: Balai Pustaka, 1993.

Putuhena Shaleh, Historiografi Haji Indonesia, Yogyakarta: PT. LKIS Pelangi Aksara, 2007.

Qomar Mujamil, Pesantren dari Transformasi Metodologi Menuju Demokratisasi Institusi, Jakarta: Erlangga, Tanpa Tahun.

Rosidin Didin Nurul, Wajah Baru Islam Indonesia, Kontestasi Gerakan Keislaman Awal Abad 20, Cirebon: Nurjati Press, 2012.

Steenbrink A Karel, Beberapa Aspek Tentang Islam di Indonesia Abad ke-19, Jakarta: PT. Bulan Bintang, 1984. 
Stoddard Lothrop, Dunia Baru Islam, Jakarta: Menteri Koordinator Kesejahteraan, 1966.

Suprapto Bibit, Ensiklopedi Ulama Nusantara, Jakarta: Gelegar Media Indonesia, 2010.

Sulasman, Metodologi Penelitian

Sejarah, Bandung: Pustaka Setia, 2014.

Suminto Aqib, Politik Islam Hindia Belanda, Jakarta: PT. Midas Surya Grafindo, 1985.

Suryanegara Ahmad Mansur, Api

Sejarah IMahakarya Perjuangan

Ulama dan Santri dalam

Menegakkan Negara Kesatuan

Republik Indonesia, Bandung:

Suryadinasti, 2014.

Suryanegara Ahmad Mansur,

Menemukan Sejarah, Wacana
Pergerakan Islam di Indonesia, Bandung: Mizan, 1995.

INTERNET

Moh Zainul Fajeri, Haji dalam Perspektif Sosial, http://tulisanterkini.com/artikel/art ikel-ilmiah/11670-haji-dalam-

perspektif-sosial.html, diunduh pada 01 Sepetember 2016 pada pukul 04.05 WIB.

Nuri Muhammad, Pragmatisme Penyelenggaraan Ibadah Haji di Indonesia, https://www.academia.edu/99900 26, diunduh pada 14 September 2016 Pukul 11.30 WIB. 